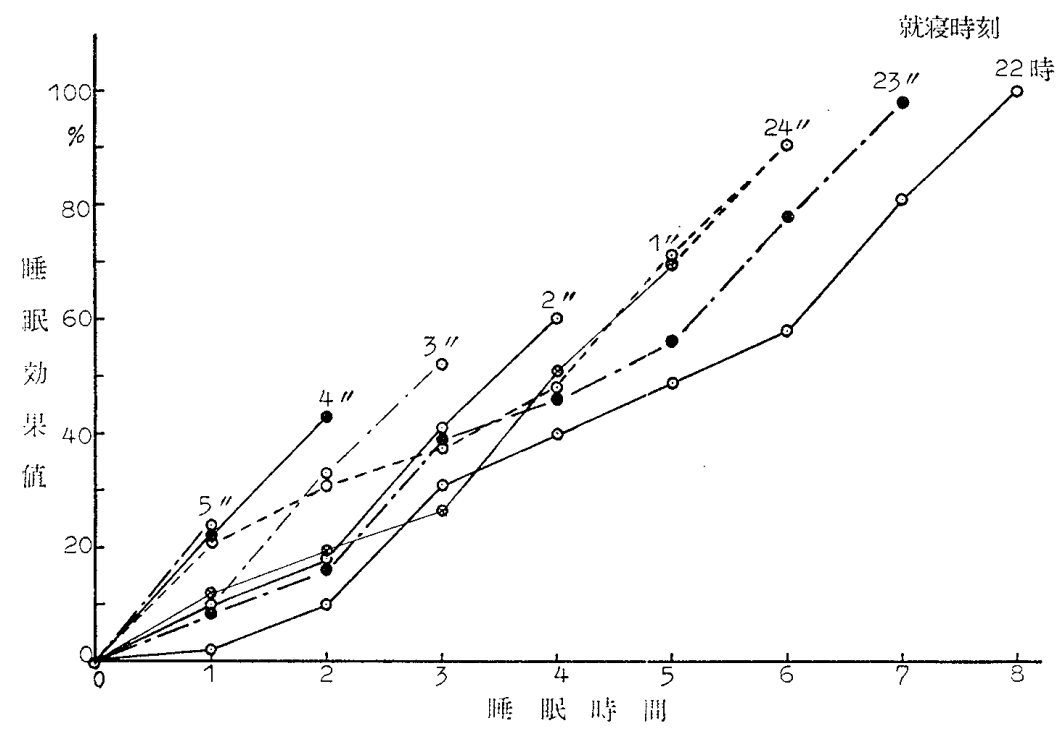

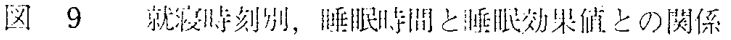

\section{V 日本における交替制の現状}

委 員 森岡三生

I． 製造業・鉱業の交替制に関する アンケート調査の概要（1962年 3 月）
1961年春，全国の製造業・鈗業の事業場学対象として 㧍こなった『交替制にかんするアンケート』調查の集計 結果の概要について郝告する。このアンケートの目的 流，製造業・鉱業で採用されている交替制度を種頪べつ ※分類し，ぞの制度がぞのくらい採用されているかる知

表 1 産業別にみた回答数，採用数と交替者比

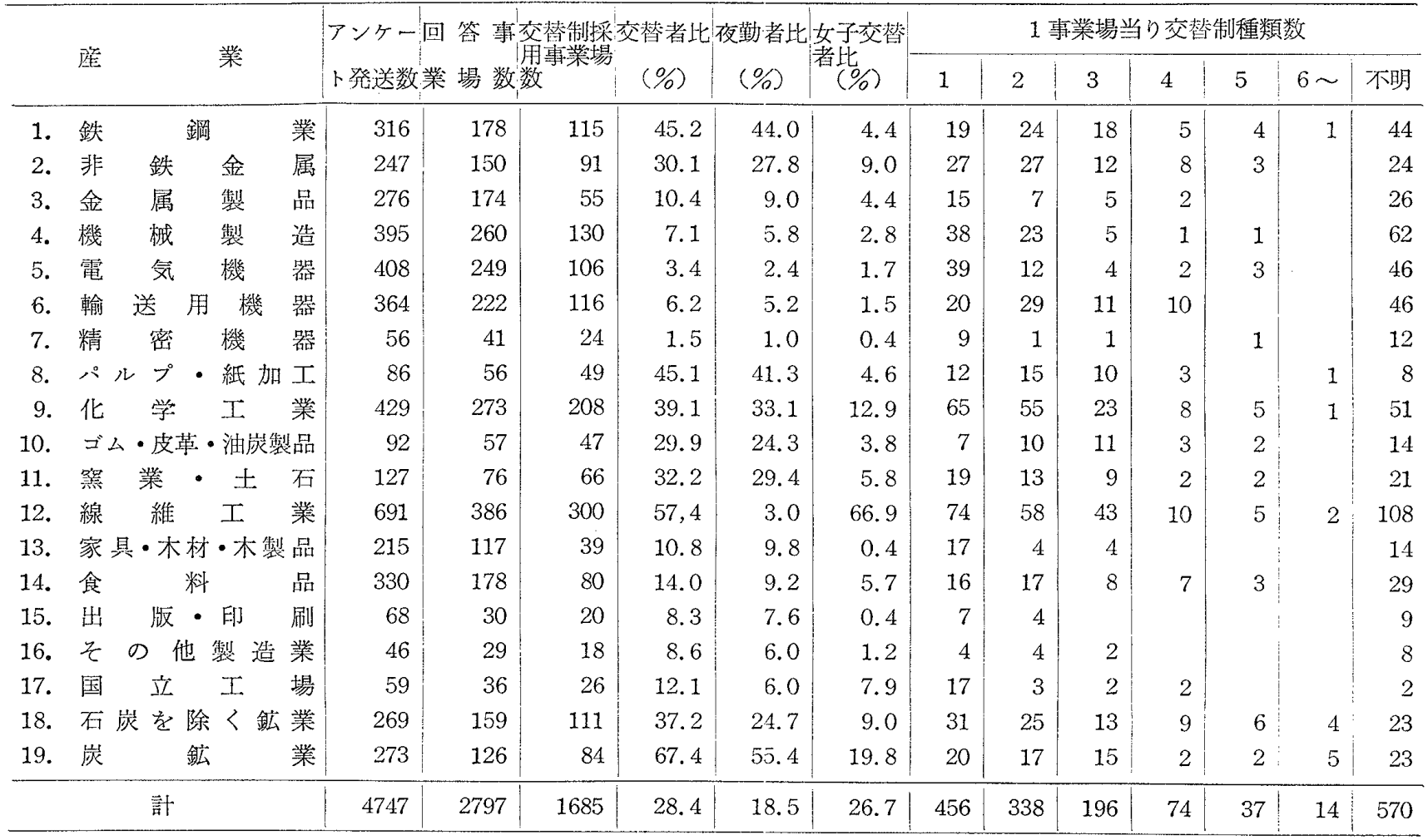

交菖者比，夜勤者比は回签事業場学偅者総数にたいする比率，女子交替者比は同女子労偅者総数にたいする比率。 
ることにあっだ。

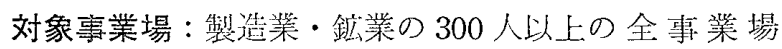
$(2,347)$ と，主な業種12（表 1 の発送数 200 以上のとこ ろ）について，10～299人の規模の事業場を200ずつ癔 別任意抽出した 2,400事業場の合計 4, 747 事業場。1961 年の 2 月から 5 月にか沙て回収された。回答事栄場数は 2,797であるが，不採用事業場と後送した往復ハガキに よって交筧者数の㝊判明した 570 事業場とを除くと, 交 替種類の判明した回答事業場は 1,115 である。

分 類 法: 表 2 にしいた分類を拈こなった。24洔

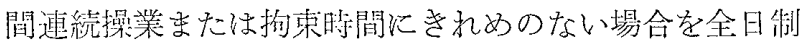

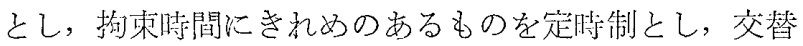
数と組数とよってわけた。一部を表 3 にしわしたよう に，さらに夙期によって小分類できる。

（1） 1 交替，2交替，3交替，多交替は1月24日明間を
いくつの直にわけるかによる。

(2) 2 組， 3 組，4縕，多組は，当該学働者をいくつ の組に維成して值勤務にふりあてるかによる（職場 がちがっても交替の直勤務が括なじものは 1 組とか ぞ党る)。

（3）週番型は，当該交替制学働者の各共通の一省公休 日があるもの。

(4) 宿直型は苴ごとの定員がことなっていて，ある組 についてみると直ごとの勤弱日数がことなる場合。 多值型は闹じく新番と後番で定員がことなる場合。

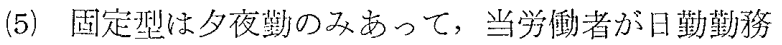
につくことのない場合。

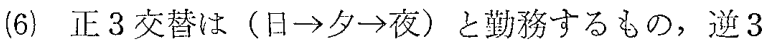
交替は（夜 $\rightarrow$ 夕日）と勤務するもの。

また，表 3 の表現型は，㨐々の交替力式をしめすもの

表 2 中分類べつにみた交替制度の採用数

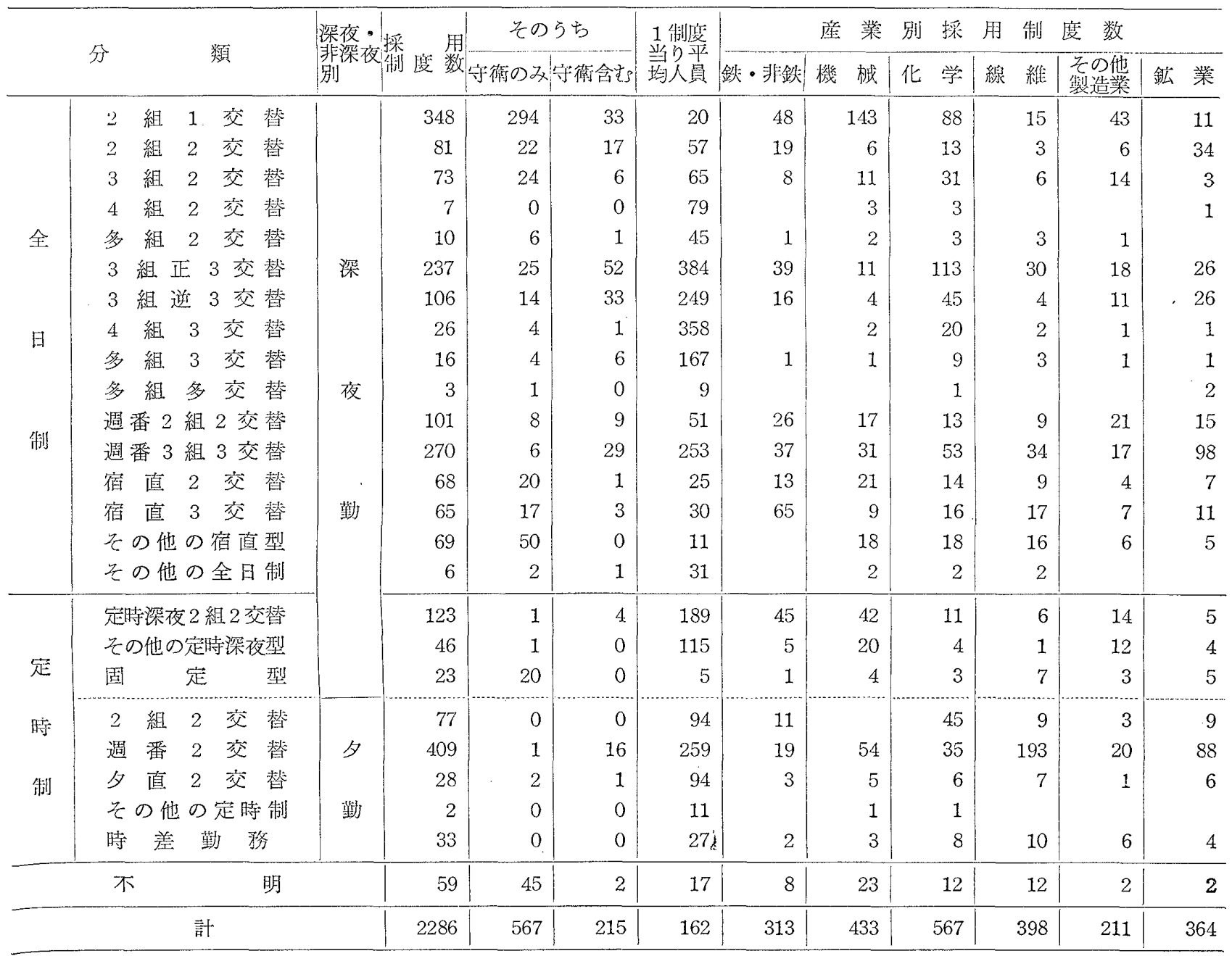

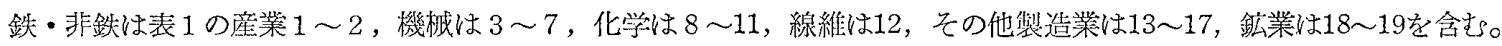
定時制の多交䓎は 1 例もなかった。 
表 3 代表的な交替制度 25 種の採用数

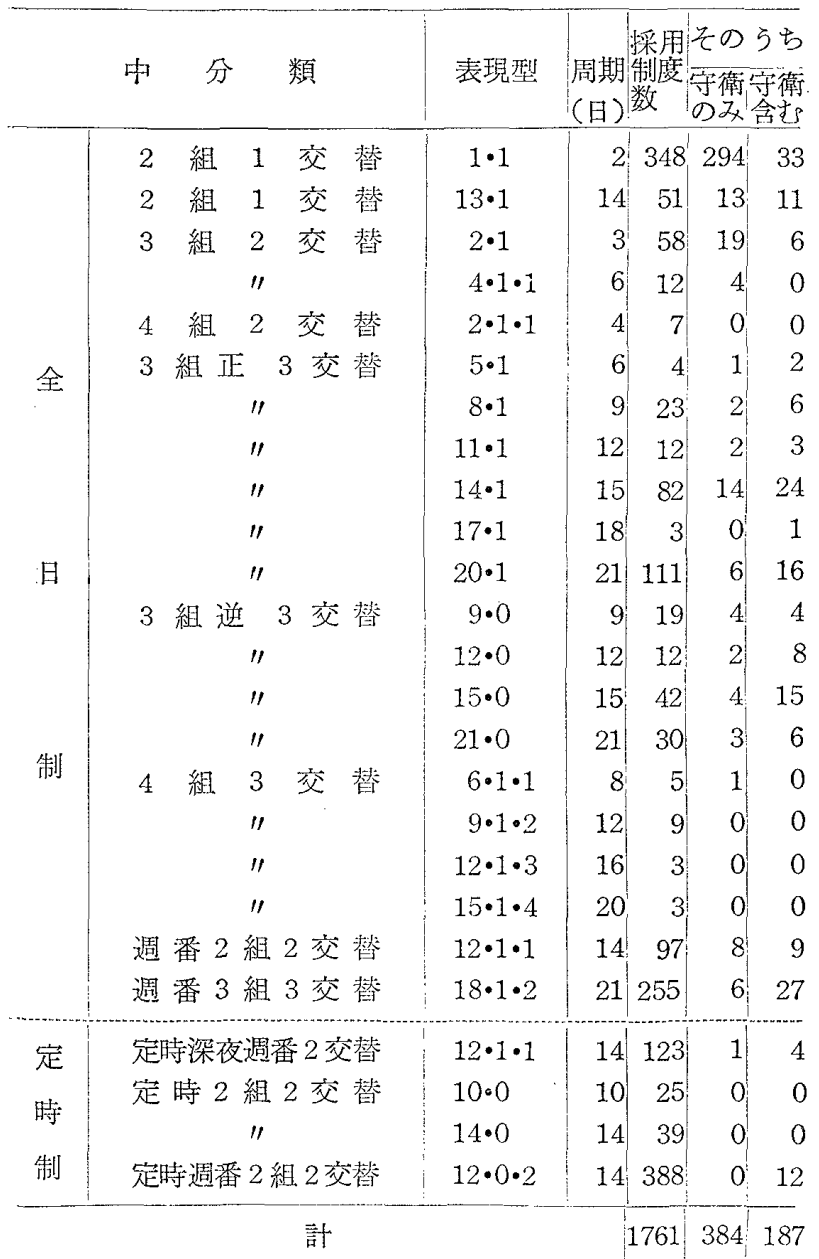

表 4 (1) 夜勤の一連続日数別にみた制度数

\begin{tabular}{|c|c|c|c|c|}
\hline \multirow{2}{*}{$\begin{array}{l}\text { 一連 続 } \\
\text { 夜勤日数 }\end{array}$} & \multicolumn{2}{|c|}{ 全 日 制 } & \multirow{2}{*}{$\begin{array}{l}\text { 定 時 } \\
\text { 樑 夜 型 }\end{array}$} & \multirow{2}{*}{ 計 } \\
\hline & 守衛のみ & 一 般 & & \\
\hline 1日 & 352 & 137 & 2 & 491 \\
\hline 2 & 43 & 31 & 3 & 77 \\
\hline 3 & 24 & 66 & 5 & 95 \\
\hline 4 & 9 & 45 & 3 & 47 \\
\hline 5 & 11 & 139 & 2 & 152 \\
\hline 6 & 22 & 404 & 145 & 571 \\
\hline 7 & 26 & 173 & 3 & 207 \\
\hline $8 \sim 11$ & 3 & 3 & 0 & 6 \\
\hline 12 & 0 & 4 & 3 & 7 \\
\hline $13 \sim$ & 2 & 0 & 0 & 2 \\
\hline 郭 & 492 & 997 & 166 & 1655 \\
\hline
\end{tabular}

（2）夕勤の一連続日数別にみた 非深夜定時制の制度数

\begin{tabular}{|c|c|}
\hline $\begin{array}{l}\text { 犝続 } \\
\text { 夕勤日数 }\end{array}$ & 制 度 数 \\
\hline 1日 & 8 \\
\hline 2 & 6 \\
\hline 3 & 8 \\
\hline 4 & 6 \\
\hline 5 & 27 \\
\hline 6 & 413 \\
\hline 7 & 44 \\
\hline $8 \sim$ & 0 \\
\hline 計 & 512 \\
\hline
\end{tabular}

表 5 各交替制の夜㰾直の長さ

\begin{tabular}{|c|c|c|c|c|c|c|c|c|c|c|c|c|c|c|c|}
\hline \multirow{2}{*}{ 分 } & \multirow{2}{*}{\multicolumn{2}{|c|}{ 類 }} & \multicolumn{12}{|c|}{ 夜勤 直 の単 位拘 束 時 間 } & \multirow{2}{*}{ 計 } \\
\hline & & & $\sim 7$ & $7 \sim$ & $8 \sim$ & $9 \sim$ & $10 \sim$ & $11 \sim$ & $12 \sim$ & $13 \sim$ & $15 \sim$ & $17 \sim$ & $20 \sim$ & $24 \sim$ & \\
\hline 1 & 交 & 替 & \multirow{8}{*}{1} & & & & & & & \multirow{4}{*}{34} & \multirow{3}{*}{$\begin{array}{r}1 \\
26\end{array}$} & \multirow{2}{*}{$\begin{array}{l}1 \\
4\end{array}$} & \multirow{2}{*}{\begin{tabular}{l|}
2 \\
1
\end{tabular}} & \multirow{2}{*}{$\begin{array}{r}344 \\
3\end{array}$} & 348 \\
\hline 2 & & 替 & & & & & & & 103 & & & & & & 171 \\
\hline 3 & 交 & 替 & & 5 & 247 & 77 & 47 & 6 & 3 & & & & & & 385 \\
\hline 多 & 艾 & 替 & & & 1 & & 1 & & & & \multirow{3}{*}{2} & \multirow{5}{*}{4} & \multirow{5}{*}{3} & \multirow{5}{*}{56} & 3 \\
\hline 週 番 & $=2$ 交 & 替 & & & 1 & 1 & & 5 & 84 & \multirow[t]{2}{*}{8} & & & & & 101 \\
\hline 週 番 & : 3 交 & 替 & & 4 & 211 & 25 & 20 & 6 & 3 & & & & & & 269 \\
\hline & 面 & 型 & & 1 & 44 & 15 & 10 & 6 & 33 & 9 & 19 & & & & 200 \\
\hline 定 時 & 樑 夜 & 型 & & 2 & 78 & 44 & 20 & 15 & 10 & & & & & & 169 \\
\hline & 計 & & 1 & 12 & 582 & 162 & 98 & 38 & 236 & 51 & 48 & 9 & 6 & 403 & 1646 \\
\hline
\end{tabular}

で，〔1 周期のなかの勤務直数】・[夜勤明け休み目数〕・ 〔夜勤明子休名以外の休日数〕の三つの整数連記による。 連勤直も一つとかどえる。さいごが 0 の場合, 略するこ とにしてある。この 3 数の合計が牊期の長さ（日数）に なる。
な和，樑夜・非深夜の別は，労慟基準法でいら区別と 沽らがって，午前 2 時以降にわたって拘束する直の勤務

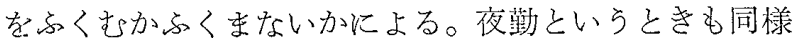
で，2時以降にわたり，徹夜ないしは翌朝にわたるをで の拊束，あるいは徹夜に近い状態での勤務をさしてい 
表 6 深夜勤務の場合の仮眠の有無と仮眠時間

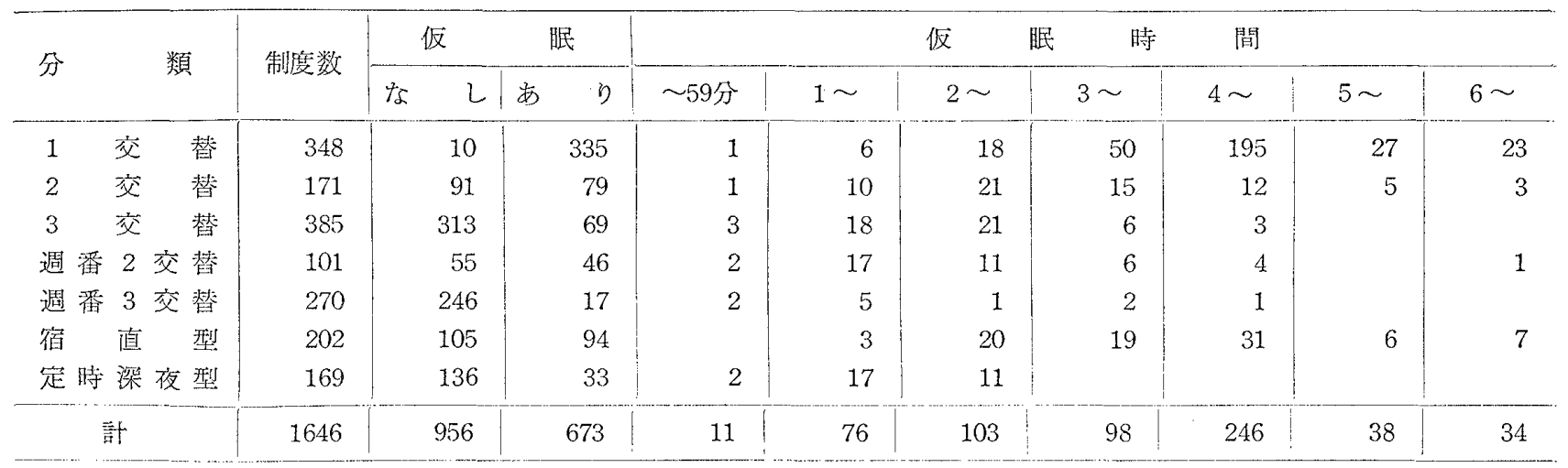

表 7 労務問題としての交替制

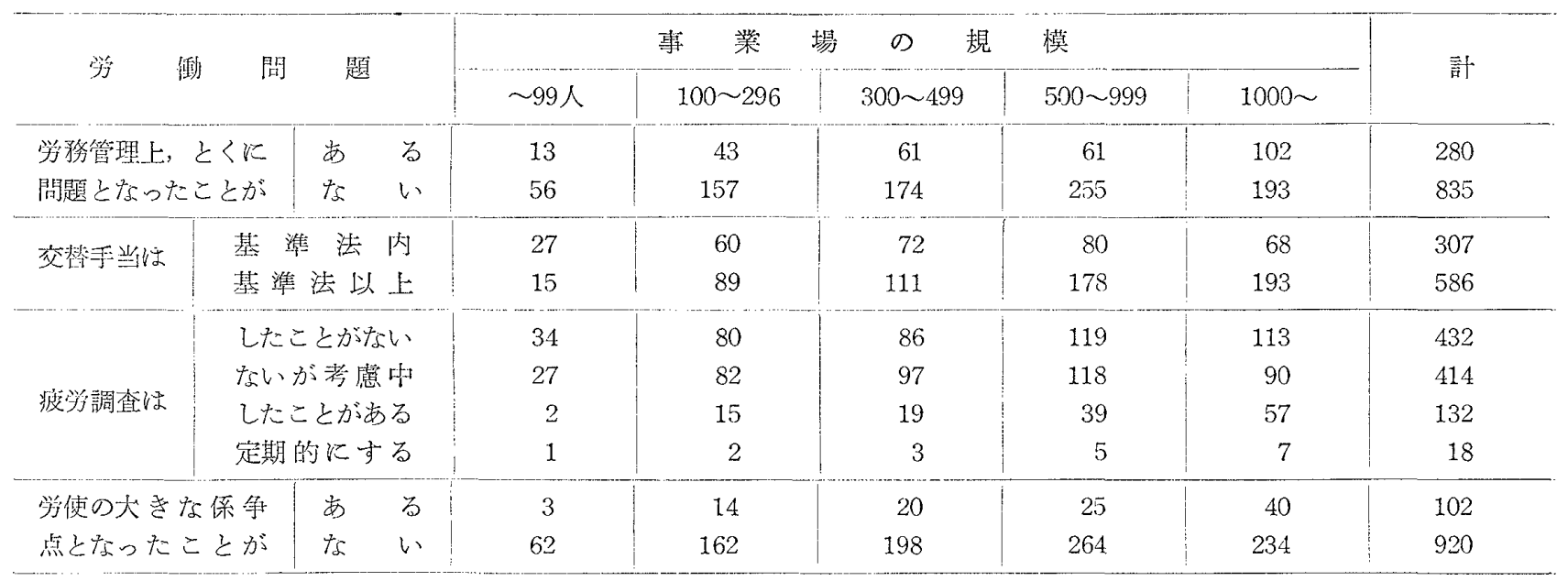

学務管理上の問題点としてあげられたものは, 直の長さ (70), 值の順序 $(35)$, 直の交替時刻 (60), 連

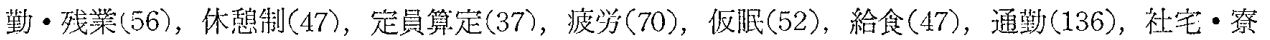
(62)，その他(48)であった。

る。

分類法については「労働の科学」16㷀7号（1961售） を参照されたい。

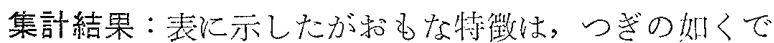
ある。

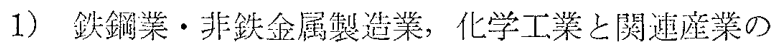

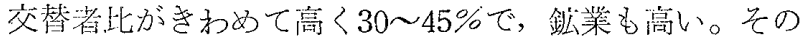
大部分は夜鞉者だが，非深苳交替者も多く，とくに綿維 工桇に特到的である。回答事業場の学働者総数 $1,697,67$ 2 人のら占， $28.4 \%$ \% 481,500 人が交替勤務者で， 18.5 $\%$ \% 313,450 人が夜勤者だった。女子は466, 665人の 26.7

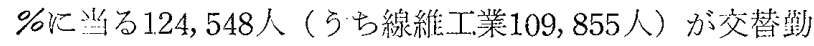
務者で，女子の99.09\%は非深夜であった（表 1 )。

2）交智制を採用していた 1,685 事業場のうち，守衛

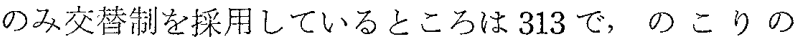
$81.5 \%$ 娃守衛以外飞なんらかの交替制を採用していた。 1 事業埸当りの交替制種類数は 2.05 で 3 種以上が 1,115
整策場中 321 も市った(表 1 )。

3）侧数のすくない 4 組 2 交替, 多組多交替をりぞい

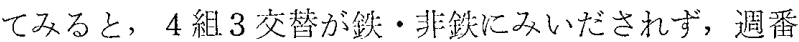
型でない非深夜 2 組 2 交替が機械工業にみいだされなか っただけで，ぞの分類の制度も各業種にみいだされ，契 に多様の交替制度が治汎に，どの美種にも注とんどもれ なく分析していた(表2)。

4）菜種べつの特徵から，(1守衛(隔日交替が40\%)， (2)化学工業 ( 3 交替連操が多い), (3)鉸業(週番 3 交替), (4)線維(非深夜週番 2 交替), (5)機械工業（週番型，之く に起時深夜型）の五つの類型が文られる(表 2)。

5）企日制の場含にも 1 交替，2交替がかなりな数に のぼる。3 交替制で注 3 組編成が大部分で， 725 例のら ち 3 組正 3 交替 $237 ， 3$ 組逝 3 交替 $106 ， 4$ 組 3 交替 26 , 多組（主と乙て7 組）16，调番型270，伯洎型 65 例であ。 った(表 2 )。

6）定時深夜 2 交替(朝夕に推束のきれ女のあるもの》 
が 169 例もみられたが，一般に残業の恒常化をともなっ ているよらである。その汪かの定時制では週番 2 交替が 王倒的飞多い(表 2 )。

7）代表的な 25 種の採用頻度はとくに高く，これら で全体の77\%の 1,761例に達し，隔日交替をのぞくと， 風期14日，15日，21日が多い(表 3 )。

8) 4 組 3 交替は 26 例及られ，6・1・1 制(112233明 休またはその変型)，9・1・2 制 (111222㐾333明休)，15

・1・4 制(11111 休 22222 休休 33333 明休)などが代表的 な例で，休日の一部を正規交替勤務外の日勤にふりあて ている場合もあった（表 $2 ， 3$ )。

9）翡深夜定時制の直転換はほとんど1週間交替であ った。媣夜覲の一連続日数はかなりいろいるで，6日， 1日，7日，5日，3日の順で，5〜7日が多いが，1 〜4日もかなりあった。長期の夜勤逨絖はごくまれだっ た(表 4 )。

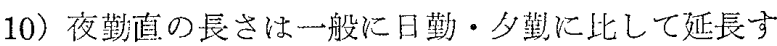
る傾向がある。一般に長㭙間の夜歏は相当多く，9時間 以上が $64 \% ， 10$ 時間以上が54\%あった(表 5 )。

11）仮眠は1交替のほとんど，2交替の $46 \% ， 3$ 交 替の $22 \%$ ，週番 3 交替の $7 \%$ に採用され，仮眠時間は 1 交替で 4 時間， 2 交替で $2 \sim 3$ 䀧間， 3 交替で $1 \sim 2$

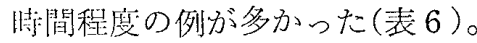

12）交替勤枒者の労務管理にはかたりの考慧がはらわ れているよらで，学使の係争点となることも少なくな く，15\%が波学調查を実施したことがあり，なお $42 \%$ が疲労調查を考慮にいれていた（表 7,8 )。

13）基準法の規定以上に，なんらかの割增または交替 手当をはらっている事業場が 3 分の 2 をしぬていた（表
7)。

14）交替勤務者は深夜・非深夜ともふえていく傾间に あるが，一方，生産工程や公共上此もを得ない場合以外 にも広汎化していく傾向がみられた。また，深夜勤務者 は35〜40才をさかいに少なくなるが50才以上のものも $5 \%$ ほ年られた。女子の交替勒務者の60\%は20才未泗 の若年者であった(表9，10)。

婊 8 人事管理・健康管理上とくに留意している点

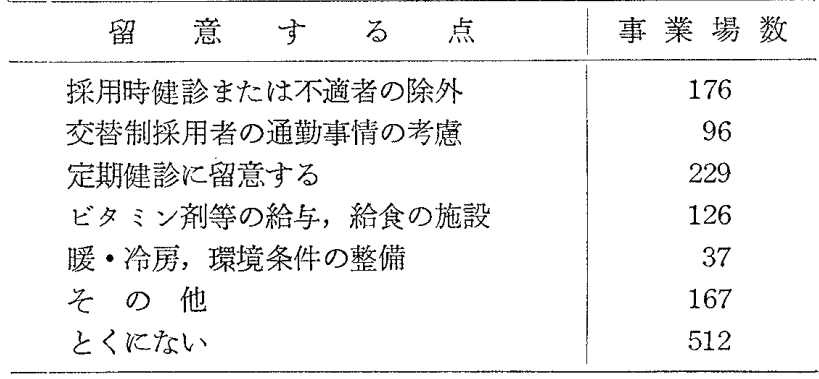

表 9 交替勤務者の増減予定

\begin{tabular}{|c|c|c|c|c|c|}
\hline \multirow{2}{*}{ 交替勤務者の增減 } & \multicolumn{5}{|c|}{ 事 業 場 数 } \\
\hline & 深 & 夜 & 非 & 深 & 夜 \\
\hline 大幅にふ党る & & 30 & & 1 & \\
\hline 若下ふ党る & & 234 & & 7 & 8 \\
\hline 大体現状のまま & & 595 & & 29 & \\
\hline 若干へる & & 39 & & 2 & 2 \\
\hline 大幅にへる & & 3 & & & 0 \\
\hline 全く廃止する & & 8 & & & 4 \\
\hline
\end{tabular}

表10 交替勤務者の年齢分布

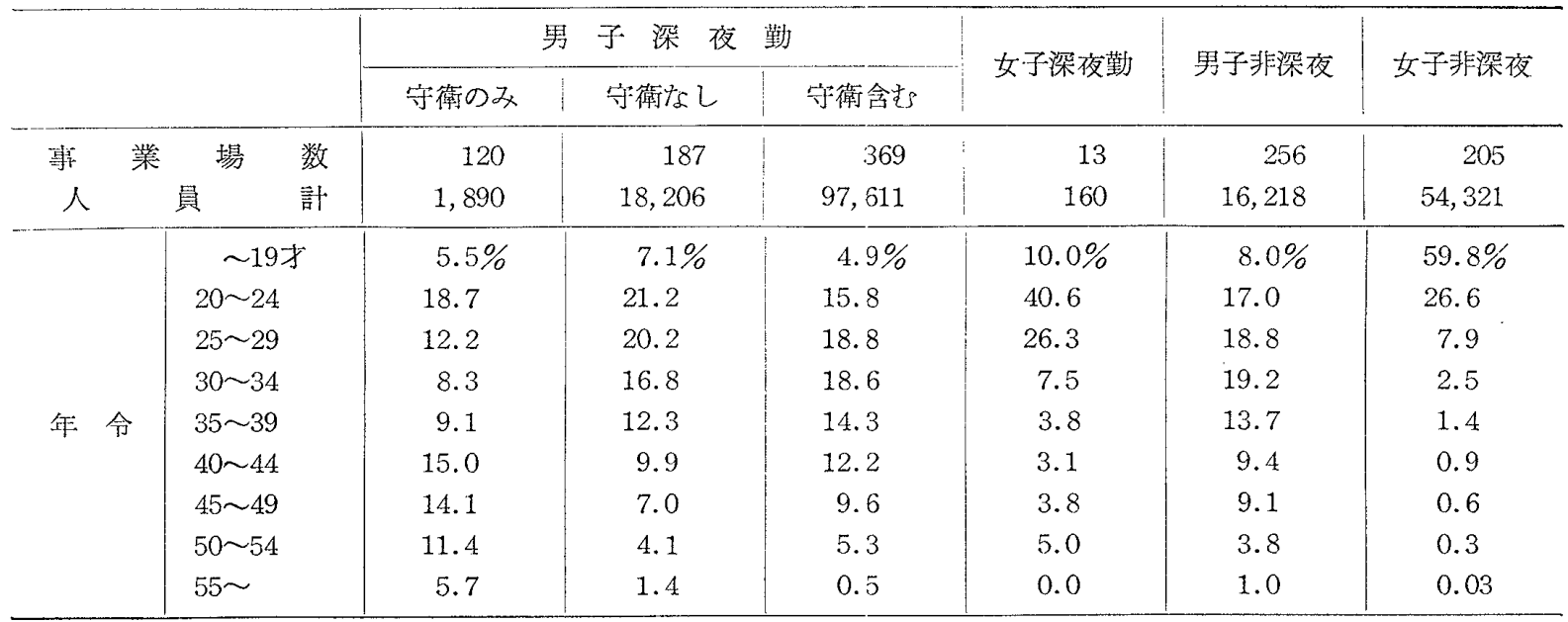

この年令分布は，記入のあったものについて比率をもとめたもの。 


\section{II. 交替勤務制の樣式の分類と エ・鉱業での現状}

\section{1. 交替制様式の分類}

(1) 1 日24眝間をいくつの勤務值に分けるかが交替数 であり，勤務者をいくつの組に編成して直にあたらせる かを組数とすると，何組何交替の様式かが分類の基本に なるが，そのほか，つぎのよな指梆を考えると様式の 内容を表現するのが容易になる。

全 日 制一一24跱間連続操業または各直の所走拊束 洔間にきれ目のないもの

定 洔 制-—そうでないもの

䓢 番型一一当硋交替制従事学働者の各組共通の一 斉公休日のあるもの

宿酉 期——直ごとの従事定員が晎なる場合。すな

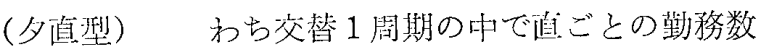
が異なるもの

正 交 替一日十ター夜の順に直がかわるもの

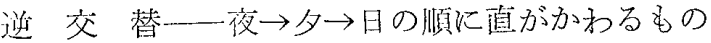

交筸の周期-D-ある直の第 1 日から，つぎにその直の 第 1 日炕どってくるまでの日数

㭙 差 型——冬組の学働時間がかなり（4 声間以 上)重なるもの

固 定 型一夕夜勒のみ勤枒するもので, 当硋学働 者が日勤墈務につくことのないもの

深 夜 型一ここでは午前 2 㭙以降にわたる勤務㨁

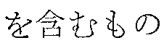

非深夜型—そらでないもの

(2) $\mathrm{A} \cdot \mathrm{B} \cdot \mathrm{C} の \equiv つ の$ 整数連記による交替様式の裴 琴型式

表 1 交替制の分類

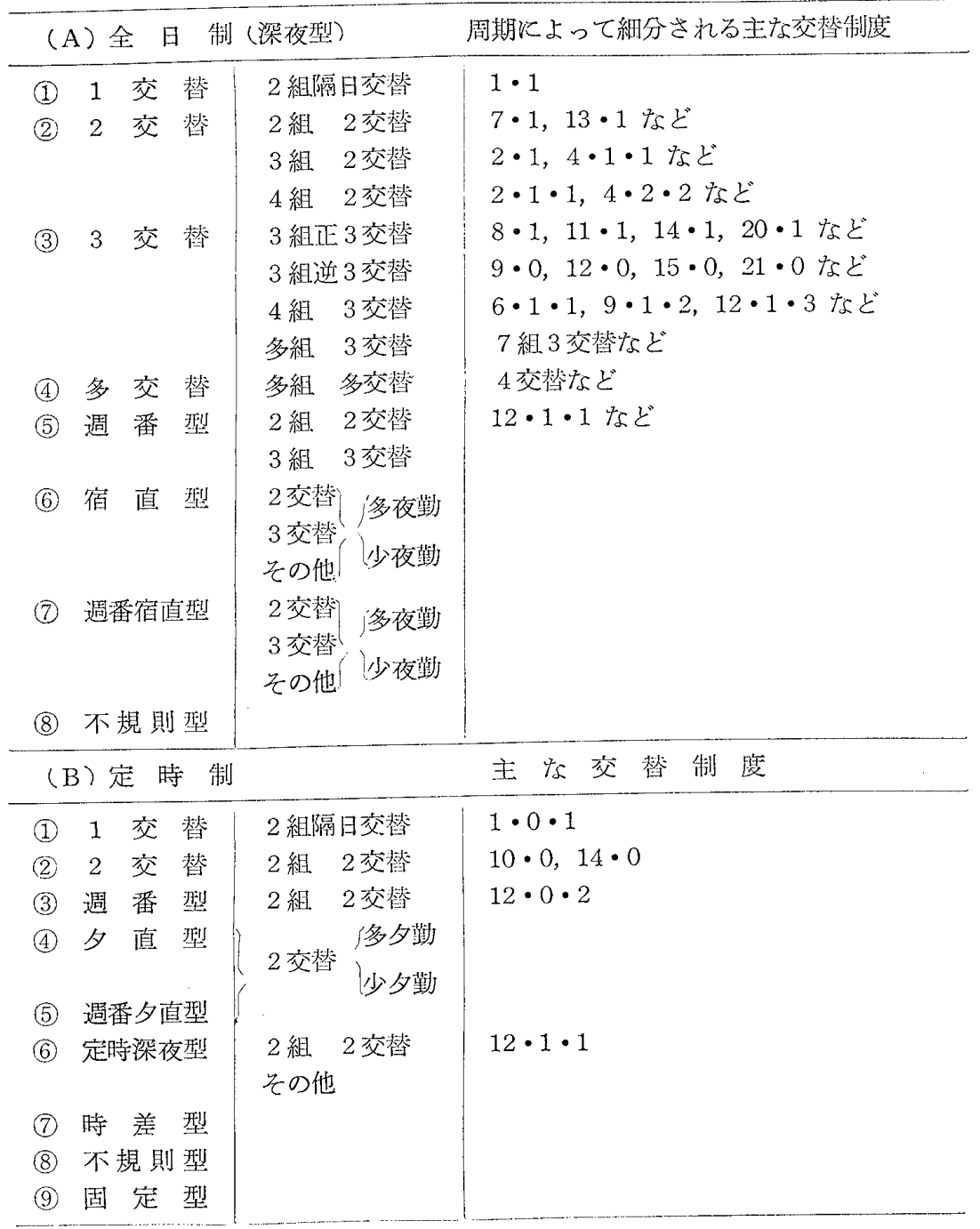


A—— 1 周期のなかの勤務值数。ただし連勱植など は一つに数える。

$\mathrm{B}$ 一夜勤明恘みの日数。

$\mathrm{C}$ 一夜勤明け休久以外の休日数（Cが０の場合は 略する)。

したがって $\mathrm{A}+\mathrm{B}+\mathrm{C} か ゙ 1$ 周期の長さ（日数）になり， 繧成組数の倍数となる。Aを交替数で割ったものは各直 の勤務日数となるが，連勤あるいは半連勤があると割り 切れない。

この表現法は何組何交替かによって，A・ B・Cの数 系に特徽がある。ただし同じ表現型にも連勤の有無，連 勤のしかたや，直の湏序，休日の捙入のしかたで变形が あり得る。

（3）いずれか 1 組の直の塠い方（系列）で交替制様式 を示方方法

萏の一般的なあらわし方

$1-8 \sim 16$ 斡内外の直 ( 1 直, 日勤, 昼勤, 朝 鋥，甲番などに当る）

$2-16 \sim 24$ 时内外の直 ( 2 直, 夕勒, 霄勒, 前夜勤, 乙乘などに当 る)

$3-24$ 翌 8 時内外の直（3直，夜勤，後夜勤， 泊り，丙番などに当る)

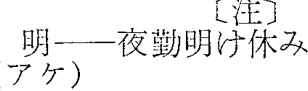

（前日または24时内外加 らの夜勤直を含む勤務が 終った日のこと）

休一一夜勤明汿の日でない休日

$\widehat{12}$ —— $\sim 24$ 㭙内外の連勤（二つの值を通し勤枒す るもの

$\widehat{23}-16$ ～翌 8 洔内外の速勤

$\overparen{123}$ 一 8 〜翌 8 時内外の一昼夜の連続勤務

$\overline{1}$ - $8 \sim 20$ 時内外の12時間前後の勤務（半逨勤の こともある)

$\overline{3}-20 \sim$ 翌 8 時内外の12時間前後の勤務（"

〔注】夜勤賏け後，つぎの直まで24时間以上あるとき， それを休日としている所もあるが，ここでは呼び 名として明にしてある。

\section{表 2 交替直方式の一般的な系列}

(A) 全 日 制

(1) 2 組 1 交替（隔日勤務）

$1 \cdot 1$ 制 $\widehat{123}$ 明

(2) 2 組 2 交替 $(1 \cdot 1$ 制は 2 組 1 交替になる)
3 ・ 1 制 $\overline{1} \widehat{123} \overline{3}$ 明(または $1 \widehat{123} \overline{23}$ 明など)

$5 \cdot 1$ 制 $\overline{1} \overline{1} \overline{123} \overline{3} \overline{3}$ 明

$7 \cdot 1$ 制 $\overline{1} \overline{1} \overline{1} \overline{123} \overline{3} \overline{3}$ 明

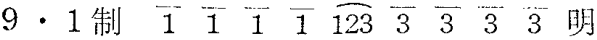

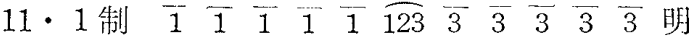

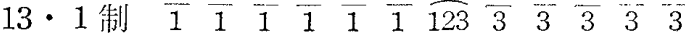
3 明

(3) 3 組 2 交替

2 ・1制 $\overline{1} \overline{3}$ 明（または $1 \longdiv { 2 3 }$ 明など）

$4 \cdot 1 \cdot 1$ 制 $\overline{1} \overline{1} \overline{3} \overline{3}$ 明休

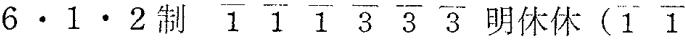
$\overline{1}$ 休 $\overline{3} \overline{3} \overline{3}$ 明休など)

$6 \cdot 3$ 制 $1111 \widehat{23}$ 明 $\overline{23}$ 明 $\widehat{23}$ 明)

(4) 4 組 2 交替

2 ・1・1制 $\overline{1} \overline{3}$ 明休（または $1 \widehat{23}$ 明休な ど)

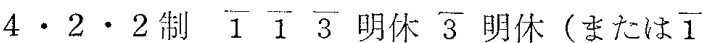
1 休 $\overline{3} \overline{3}$ 明休休などいるいる)

$6 \cdot 3 \cdot 3$ 制 $\overline{1} \overline{1}$ 休休 $\overline{3}$ 明 $\overline{3}$ 明 $\overline{3}$ 明 休

(4 組 2 交替のように休日の多く なるものは変形飞多く考光られ る。また休日の一部を予㑲直，作 業内容の異なる日勤などに当るこ とも多い。 4 組 3 交替でも同様）

(5) 3 組正 3 交替（正 2 ・ 1 制は 3 組 2 交替になる）

正 5 ・1制 $1 \overparen{12} 2333$ 明（または1 $1 2 \longdiv { 2 3 } 3$ 明, 1 1 2 3 3 明など)

正 8 ・ 1 制 $11 \widehat{12} 22333$ 明（または11 22333 明など)

正11・ 1 制

正14・1 制 $\}$ 略

正20・1 制

(6) 3 組逆交替

逆 $3 \cdot 0$ 制 321

逆6 - 0 制 332211

逆 $9 \cdot 0$ 制 33322211

逆12・0 制 3333222221111

逆15・0 制 33333322222111111

逆18・0 制

逝 $21 \cdot 0$ 制 $\}$ 略

(7) 4 組 3 交替

$3 \cdot 1 \cdot 0$ 制 123 明

$6 \cdot 1 \cdot 1$ 制 112233 明休

$9 \cdot 1 \cdot 2$ 制 111222333 明休休（または

111222 休 333 明休や112

221 休休 333 明など

$12 \cdot 1 \cdot 3$ 制 111122223333 明休休休 (同上)

(4組3交替は直の順序を变光た り，休日をはさんだり連衡を入れた り変形も多く, 近の直順换もできる)

(8) 多組交替

7 組 3 交替 

$6 \cdot 1$ 制
$\begin{array}{lllll}1 & 12233 & \text { 明 }\end{array}$
$18 \cdot 1 \cdot 2$ 制
111111 休 222222 休 33 3333 明

6 組 2 交替

$4 \cdot 2$ 制

9 組 2 交替

$6 \cdot 3$ 制

11 23明 23 明（12㭙閻型でもよい）

111 23明 23 明 $\widehat{23}$ 明（12時間型でも 5い)

(多組交替は定員の多い職場ではとり やすい)

(9) 週番型 2 組 2 交替

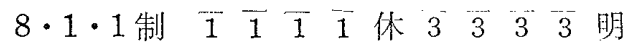

$12 \cdot 1 \cdot 1$ 制

(10)

\section{週番型 3 組 3 交替}

$15 \cdot 1 \cdot 2$ 制 11111 休 22222 休 3333 3 明

18・1・2制 1111111 休222222 休 3 $\begin{array}{lllll}3 & 3 & 3 & 3 & 3\end{array}$ 明

（週番型では明けを公休比数学るの が普通）

(11) 宿直型の例

4 組 2 交替

$3 \cdot 1$ 制 12 穴明

5 組 2 交替

$3 \cdot 1 \cdot 1$ 制

$4 \cdot 1$ 制

$1 1 \longdiv { 2 3 }$ 明休

（伩間の定員は $1 / 2 に な ~$

11123 明（夜間の定員は $1 / 3$ にな る)

5 組 3 交篦

$$
4 \text { ・ } 1 \text { 制 } 112 \text { 23朋 }
$$

週番宿值型 3 組 2 交替

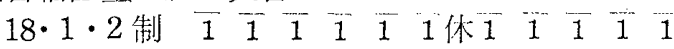
$\begin{array}{lllllll}\overline{1} \text { 休 } & 3 & \overline{3} & 3 & \overline{3} & 3\end{array}$

週番宿直型 4 組 3 交替

$24 \cdot 1 \cdot 3$ 制 1111111 休 1111111 休 22 2222 休 333333 明

（宿直型は周期, 組数, 交替数, 定 員比率などで稞頪も多い。定買比率 が夜勤直で多くなる場合もある。表 現型も奮淔型といわないと区別し期 w)

(B) 足 洔 制

(1) 2 組 1 交替

$1 \cdot 0 \cdot 1$ 制 $\widehat{12}$ 休

(2) 2 組 2 交替

$2 \cdot 0$ 制 12

$10 \cdot 0$ 制 1111111222222

14. 0 制 111111111222222

(3) 週番型 2 組 2 交替

$12 \cdot 0 \cdot 2$ 制 111111 休222222 休

(4) 週番定時深夜型 2 組 2 交替

12・1・1制 1111111 休 333333 明

(5)夕直型（宿直型）略

\section{2. 交替制様式の現状, 業種別特徵}

1961年に行なった工・䥽業事業場に対する交替制に閦 するアンケート調查（前述，17一-21頁）にもとずき，日 本に执ける交替制様式の現状での業種別特徵と, あわせ

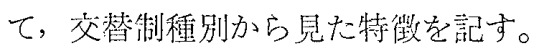

(1) 業種別特徵

(1)等衛 (隔日交替) (2)化学工業 (3 交替連操型) (3) 鉣策（週番 3 交替）(4)線維（非深夜週番 2 交替) (5) 機械工前（週番型とくに定時深夜型）

の王つの頪型が見られる。これらの類型は守衛の隔日交 替を除いて從事者も多い。

守衛の交替制 782 小，1交替（隔日）327（42\%)，2 交替114(14\%)，3交替 194（25\%）と長时間勤務をさけ る候向もある。しかし宿植型で夜勤がより多い型も守衛 には多い。

鉄鋼——化学と機栈の中間になり，3 組 3 交替正15 日または21日週期, 週番 3 組 3 交替, 週番 2 組 2 交替, 定時深夜型 2 組 2 交替が多い。 非鉄金属——鉄銅に類似するが逝 3 組 3 交替がふ学る。 非深夜 2 交替も見ら机る。

機械一一最近, 重機械, 車輛, 造船などに定時深夜

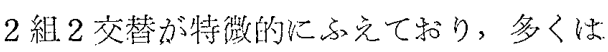
残栄の恒常化を伴ら。これは本来小ら非深 夜 2 交替なり调番 3 組 3 交替になるべきも のでこの型も見られる。動力たど補助部 門で注宿直型や 2 交替，1交替も少なくな い。精密機械は交替制が少ない。

化学——3 組 3 交替が中心であるが, 逆 3 交替（短 周期となる）の比率が亶い（パルプ，肥 料，化成品，セメントなど）化䋐関係で 4 組 3 交替が特街的飞芫られ，7組 3 交替な どもある。週番 3 交筫（パルプ，化学，ゴ ム）も少なくなく，また製品部門など（七 メント，紙，化纎など）では非深夜 2 組 2 交替も多い。石油では 3 組 2 交替 ( 4 組 2 交替) が多く見られる。補助部門は宿直型 や2交替もあり，守衛などでも隔日交替よ り 2 交替，3交替の比重が高い。䋊・パル プでは定期修理などによる月 1 亿 回の操 業中此がある。

線維一一非深夜週番 2 組 2 交替（女子）が圧倒的。 他産業の女子 2 交替では年”前 6 ～7時始業 
か午後 8〜9 時終業が多いのに比し，5时 〜22時は特徵的。動力など補助部門は 3 交 替や宿㨁型となるほか，守衛の隔日交替は 至って比重が低い。

その他の一一木製品， 2 組 2 交替（深夜型）が多い。企 製造策品は化学に類似している。印刷は, 機械に 似て週番定時深夜 2 組 2 交替が多い。国立 工場は守衛を除き交替制は比較的少ない が，種類はいろいろ。

鉣

葁——石炭では週番 3 組 3 交替の比重は金属山よ り高く, 非深夜调番 2 交替や全日制 2 組 2 交替も多小。金属山も週番 3 組 3 交替, 非 深夜週番 2 交替が多いが，精鍊所などでは 化学工業に似て 3 組 3 交替（正逆）守衛の 罊日交替は少ない。

（生産補助部門の交䣠制は從事数が少ない 割に，実状に応じかなり多様になる。病院 看護㷌(宿直型多し), 厚生施設彷事者の交

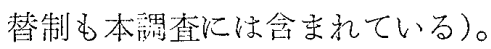

（2）交替制種別から見た特徵

(1) 2 組 1 交篡—-350例中, 守衛は $90 \%$ 守衛外も $20 \%$

(2) 2 組 2 交替— 80 例中, 守衛も半数だが, その他 も70\%, $9 \cdot 1$ 制もあるが, $13 \cdot 1$ 制 が多く，交替日の連勤（24诗間拘 束）を半数がとる。石炭鋝羔に多 く,ついで鉄鋼, 化学にある。

(3) 3 組 2 交管一-73例中, 守衛も $1 / 4$, 主に化学で $2 \cdot 1$ 制が大半。

(4) 4 組 2 交替一少ない。全部変望, 不油, パ プ，韭敘に見る。

(5) 多組 2 交替一少ない。汇とんど等衛。

(6) 3 組正 3 交替一 240 例， $1 / 3$ は連勤型 ( 1 - 2 正連多 し)，他は半連勤（12時間型 $\overline{1}, \overline{3}$ ) 徫も80例近い。 $20 \cdot 1$ 制一111例 $14 \cdot 1$ 制- 82 例, $8 \cdot 1$ 制一25例。

(7) 3 組逆 3 交替-106 例, 化学, 金属精鍊にあって 鉄鋼に少ない。守衛 47 例。3 直前 の直間隔時間最長（32時間）が㴽 とえど $15 ・ 0$ 制 $>21 ・ 0$ 制 >9・0 制>12・0制の順に少ない。

(8) 4 組 3 交替—-26例, 化緎が大半, 半数纤変形, $15 \cdot 1 \cdot 4>12 \cdot 1 \cdot 3>9 \cdot 1 \cdot 2>6$ $\cdot 1 \cdot 1 \cdot$ の頵。

(9)多組 3 交替—- 7 組 3 交替が16例で化学に多し。
(10)週 番 型— 2 組 2 交替 100 例, 3 組 3 交替 270 例。前者は鉄銅，金属，炭山，木 材などに多い。後者は鉱業の外, 線維, 化学, 鉄, 非鉄, 機械な. ど, 守衛にも35例。

(11) 宿 㨁 型—-200例中, 2 交替の $1 / 2,3$ 交替の $1 / 2$ ，その他の大半は守衛で，夜 勤日数がかえって守衛でふ觉る。 一般には $3 \sim 4$ 組䌮成で夜勤がよ り少なくなり，週番型も多い。非 週番型でも連勤を含毛例もある。 夜間は操業度も低まる補助生産部 門により多く見られる。

(12)定时深夜 2 交替一169例中， 2 維 2 交替は 123 例。 调番型で機械，鉄䞒に多い。その 他は宿面型。これらは一般に残業 の恒常化を伴い，勤務獎間も長く なりやすい。

(1B) 固 定 型一守衛汇多い。

(14) 非深夜 2 組 2 交替一77例, 化学に多い, 化瀻など の製品部閒。

(15) 週蕃型非深夜一409例，線維に多いが，鉣業，機 2 組 2 交替 珹, 化学など一般に多い。

(16) 夕 直 型一一夕勤がより少なくなるものが大半

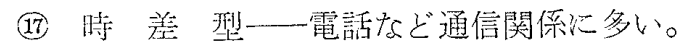

\section{VI 交替勤務制による睡眠時間の実態調査成績}

$$
\text { 委 員 森岡三生 }
$$

交替酄陊者の涶眠時間を，交替制様式に伴亏各種直間 との関係で笑態を知ることは重要である。ここにかかげ た淍查成績 I〜代は，本委員会で1964年 2 月〜 6 月にか. け，各種事業沂で，生活懗間記入力式によるアンケート 調查から睡眠㭙間，椇食㭙刻についてまとめたものであ。 る。X〜XVIは労研生理学研究室でこれまで行われた調 查を集绿した。

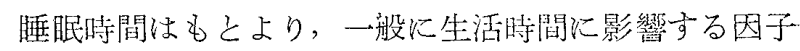
として交替勤務の椂式は重要なものであるが，事業所の 地域性によってもまた, 若干成績は異なってくる。従っ てここでは生の資料として，集計成績そのものを揭げる こととした。 